\title{
The usability analysis of using augmented reality for linus students
}

\author{
Kamariah Awang, Syadiah Nor Wan Shamsuddin, Ismahafezi Ismail, Norkhairani Abdul Rawi, \\ Maizan Mat Amin \\ Faculty of Informatics and Computing, Universiti Sultan Zainal Abidin (UniSZA), Malaysia
}

\begin{tabular}{l}
\hline \hline Article Info \\
\hline Article history: \\
Received Sep 17, 2018 \\
Revised Nov 19, 2018 \\
Accepted Nov 30, 2018 \\
\hline
\end{tabular}

Keywords:

Augmented reality

LINUS

Mobile application

Usability

\begin{abstract}
Mobile technology with Augmented Reality has become popular worldwide with a broad range of users, including students from all levels of education and the impact of mobile technology in classrooms has been extensively studied. This technology can be the source of motivation for LINUS students especially students with disabilities. The word usability also refers to the methods to improve the ease of use during a design process. Among the difficulties in teaching a LINUS student is the lack of visual media for understanding the subject especially in basic mathematics such as evaluating a number and calculating the number. The objective of the study was to evaluate the usability of using Augmented Reality in a mobile application among LINUS students in primary schools. This study used survey data gathered from 32 LINUS students of 3 different primary schools in Marang and Kuala Terengganu Districts. The questionnaire collected data on five construct of usability test to the LINUS students. The students used the mobile application while being guide by their teacher. They navigated all the buttons provided and answered the quiz too. The criteria of usability test consist of five constructs. The students showed a significant interest in learning numbers by actively participating in the LINUS sessions. The usability level was measured based on the five constructs. In summary, the augmented reality mobile application has a great potential to be used in teaching and learning, as in the Malaysia Education Development Plan 20132025 especially on the LINUS students.
\end{abstract}

Copyright (C) 2019 Institute of Advanced Engineering and Science. All rights reserved.

\section{Corresponding Author:}

Syadiah Nor Wan Shamsuddin, Faculty of Informatics and Computing, Universiti Sultan Zainal Abidin (UniSZA), Malaysia. Email: syadiah@unisza.edu.my

\section{INTRODUCTION}

The new tool and technology with augmented reality is trending in education. It helps teachers in guiding the Literacy and Numeracy Screening (LINUS) students during the sessions in the classroom [1]. The LINUS programme was introduced as a focus area of the education's National Key Results Area (NKRA) of the Government Transformation Programme (GTP) in 2013 [2]. The objective of the program is to offer an established and strong foundation in basic literacy and numeracy skills during the first three years of the Malaysian schooling system. The do screenings every year in order to identify students who are facing difficulties in basic arithmetic. The identified students will have to participate in a LINUS-dedicated remedial class hoping that their performance will improve [3]. Usability in terms of the general acceptance of a system includes social acceptability and practical aspects such as reliability, cost, compatibility, and usefulness. The other meaning of usability is a quality attribute that assesses how easy user interfaces are to be used. The usability can be improved by using technology. The implementation of technology in the teaching of primary schools especially those involving weak students known as LINUS students are widespread. 
Yet there are further studies that do not utilize the use of technology [4-6]. The effectiveness of the use of technology has been proven in teaching and learning especially in the use of multimedia components [7].

\section{ARBEST APPLICATION}

Augmented Reality (AR) is one of the most popular multimedia technologies in today's teaching session. The augmented reality features that can illustrate realistic 3D objects help students to better understand the concept or object of a subject [8]. Research involving the usage AR for teaching students with disabilities are gaining on the subject of mathematics, as students are able to see how the calculations and numbers are visually presented [9]. Therefore, the use of augmented reality in teaching disabled students especially for the LINUS program in primary schools is very promising. Among the recent studies using augmented reality as an auxiliary medium for primary school teaching LINUS students' in mathematics which is Augmented Reality - Belajar Asas Nombor Secara Interaktif (ARBEST) [9] has also been used as a guide. ARBEST is a mobile application using Augmented Reality focusing on learning basic numbers for LINUS year 1 in primary school. This mobile application has two buttons to navigate, which are "kenali nombor asas" and also "kenali matawang". After the LINUS student learns from the application, they can then try to answer the quiz. ARBEST uses three important theories namely cognitive load theory, intrinsic motivation and compensatory teaching [9]. The ARBEST conceptual framework is used as it enhances the spirit of learning, making learning more interesting with the presence of interactive multimedia elements as well as attracting students' interest [10]in knowing the basic number of mathematics.

\section{METHODS}

\subsection{Design}

The participants were LINUS Year One students of Sekolah Kebangsaan Kubu, Marang, Sekolah Kebangsaan Tok DIR and Sekolah Kebangsaan Undang, Kuala Terengganu. A total of 32 participants ( 8 female and 24 male) were recruited for this experiment.

\subsection{Instruments}

\subsubsection{ARBEST}

ARBEST operates on a smart phone, tablet or standard PC. There are two modules in ARBEST which is Menu Kenali Nombor and Menu Kenali Matawang. Each module has one augmented reality and inauguration exercise module.

\subsubsection{Feedback Questionnaire.}

The questionnaire features twenty questions according to the usability test [11], the answers to which will produce a score of between 1 and 5 using the Likert Scale [12-14]. The questionnaires assess the participant's; ease of use, construct of usefulness, construct of self-efficacy, construct of compatibility and construct of using intention.

\subsubsection{Procedure}

First, students were formed into small groups. Then, each student was trained to use the application. After the training, the student will carry out the real experiment. Then, the teacher will ask students to answer the quiz in the application to see how far they understand. Then, the students, with the help of teacher will answer the questionnaire given.

\section{RESULT AND DISCUSSION}

Usability evaluation of any system is essential to ensure systems meet both design specifications and user requirement criteria. Usability can be defined as the degree to which something is able or fit to be used [15]. This section only focused on user satisfaction based on the questionnaire given.

To evaluate the usability of our prototype application, ARBEST, we undertook a user evaluation study with 32 participants. The questionnaire was based on participants' responses on a five-point Likert Scale (strongly agree, agree, undecided, disagree, strongly disagree). The responses are summarised in Figure 1-5.

\subsection{Construct Ease of Use}

The questions are focused on the usability of the construct which concentrates on the ease of use which is referring to the fact that learners believed that ARBEST can promote their efficiency in learning 
numbers. The result shows that the application is easy to use and also helps the students in understanding the learning of numbers [16]. Moreover, the students" "perceived ease of use" indicate that the difficulty and challenges of the augmented reality application conform to the knowledge and skill level of the LINUS students, hence, instead of experiencing anxiety, they were able to engage in the tasks with a feeling of enjoyment [17].

The q1, q2, q3, q4 represent the question number for each construct as Table 1. All the students had strongly agreed that learning ARBEST through mobile phone is easy for them. As we can see, they had fun accessing the application because it is easy for them to navigate. For q2, the average is 4.9 students think that learning ARBEST through mobile phone can saves time, while only one student disagreed. All the students strongly agreed that learning ARBEST through mobile phone is convenient for them. The average is 4.9 students think that learning ARBEST through mobile phone is easy to use and they enjoyed it, while only one student disagreed as shown in Figure 1.

Table 1. Questions for Construct of Ease of Use

\begin{tabular}{ll}
\hline 1. & CONSTRUCT OF EASE OF USE = referring to the fact that learners believed that ARBEST can promote their efficiency in \\
learning numbers.
\end{tabular}

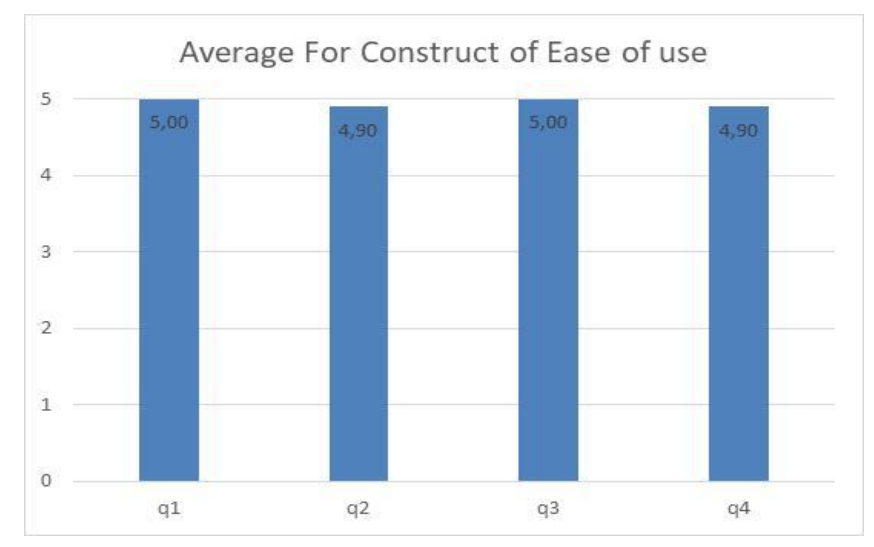

Figure 1. Average for construct of ease of use

\subsection{Construct of Usefulness}

The second construct is the Construct of Usefulness and refers to Table 2. They believe that learning numbers through mobile phones can save time and learning ARBEST through mobile phones is convenient. There are 22 from the 32 students think that by using ARBEST through mobile phone, they are not restricted by time and place, while six students still agree with 22 students and about 2 students disagree and also strongly disagree with the criteria. For the second question, about 29 students think that using ARBEST through mobile phone can help them in learning numbers while three students disagree. In the third question, about 29 students too think that using ARBEST through mobile phone can enhance their learning of numbers while three of them disagree, while question number four, about 30 students strongly agree that by using ARBEST through mobile phone, it provides helpful guidance for answering the quiz, while two of them disagreed with that, as shown in Figure 2.

Table 2. Questions for Construct of Usefulness

\begin{tabular}{ll}
\hline 2. CONSTRUCT OF USEFULNESS = They believed learning numbers through mobile phones can save time while learning \\
ARBEST through mobile phones is convenient. \\
\hline q1 & Using ARBEST through mobile phone is not restricted by time and place \\
q2 & Using ARBEST through mobile phone can help me in learning numbers \\
q3 & Using ARBEST through mobile phone enhance my learning numbers \\
q4 & $\begin{array}{l}\text { Using ARBEST through mobile phone provides helpful guidance in answering } \\
\text { question (quiz) }\end{array}$ \\
\hline
\end{tabular}




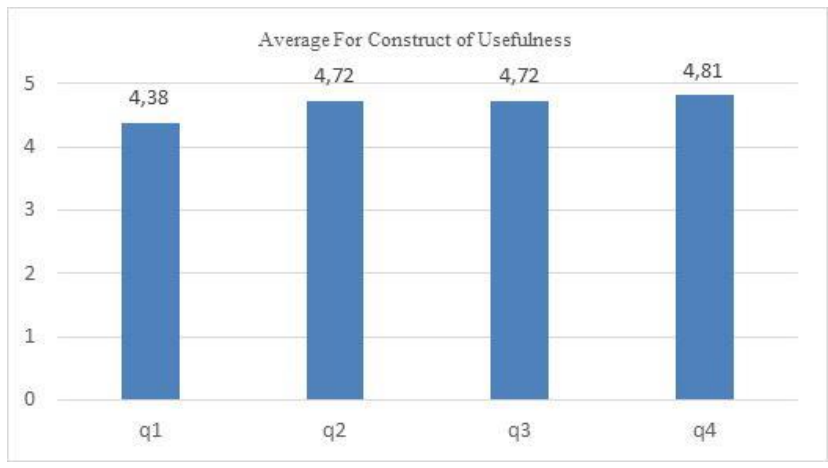

Figure 2. Average for construct of usefulness

\subsection{Construct of Self- Efficacy}

The third construct is the Construct of Self- Efficacy and refers to Table 3. According to the innovation of the Diffusion Model Theory, the definition of Self- Efficacy is defined as users' ability of using mobile application through the mobile interface. For question number one, 27 of students can complete learning ARBEST tasks through mobile phone if there is no one around to tell them what to do, while only five students still need to be guided by someone especially the teacher. 24 from the 32 students could complete learning ARBEST tasks through mobile phone if someone had helped them to get started, while eight students still need to be help when to complete the task in ARBEST. Only 19 students could overcome the difficulties encountered when they used mobile phone to learn ARBEST, while 13 students still do not think that they can overcome if any problem happened. About 19 of students could complete learning ARBEST tasks through mobile phone no matter the mobile phone or how difficult is, while 13 students still could not complete learning ARBEST tasks, as shown in Figure 3.

Table 3. Questions for Construct of Self-Efficacy

\begin{tabular}{ll}
\hline 3. CONSTRUCT OF SELF-EFFICACY = According to Innovation Diffusion Model theory, the definition of Self-Efficacy \\
was defined as users' ability of using mobile application through mobile interface
\end{tabular}

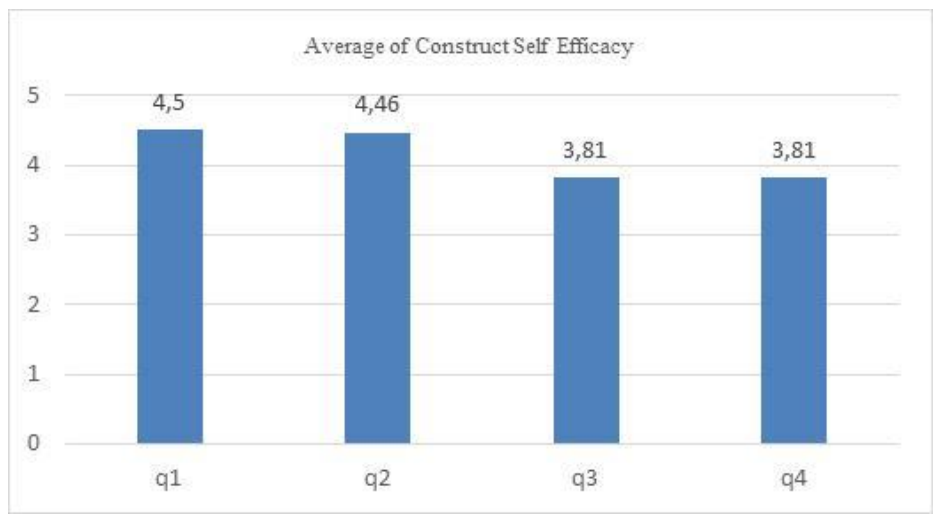

Figure 3. Average for construct of self-efficacy 


\subsection{Construct of Compatibility}

The fourth construct is the compatibility which is according to Innovation Diffusion Model theory. Compatibility refers to the fact that users believe that learning numbers through mobile phones were related to users' life experiences, and refers to Table 4. For the first question, 17 students said that to learn ARBEST via the mobile phone, they don't have to change anything in their mobile phone that they currently have. For this question, 23 students think that by using ARBEST through mobile phone they feel that it does not require significant change in their existing work routine. For question number three, 17 students think that using ARBEST through mobile phone is the same as using other mobile applications or software that they had used in the past, while nine students just agree, four students disagree, and two students don't think that using ARBEST is the same as using other software. All the students had strongly agreed that using ARBEST can reinforce learning from tablets too, as shown in Figure 4.

Table 4. Questions for Construct of Compatibility

\begin{tabular}{ll}
\hline $\begin{array}{l}\text { 4. CONSTRUCT OF COMPATIBILITY = According to Innovation Diffusion Model theory, compatibility refers to the fact } \\
\text { that users believed that learning numbers through mobile phones was related users' life experiences }\end{array}$ \\
\hline q1 & $\begin{array}{l}\text { To use learning ARBEST through mobile phone, I don't have to change anything I } \\
\text { currently do. }\end{array}$ \\
q2 & $\begin{array}{l}\text { Using ARBEST through mobile phone does not require significant changes in my } \\
\text { existing work routine. }\end{array}$ \\
q3 & $\begin{array}{l}\text { Using ARBEST through mobile phone is same as using other software I have used } \\
\text { in the past. }\end{array}$ \\
q4 & Using ARBEST through mobile phone can reinforce from tablet \\
\hline
\end{tabular}

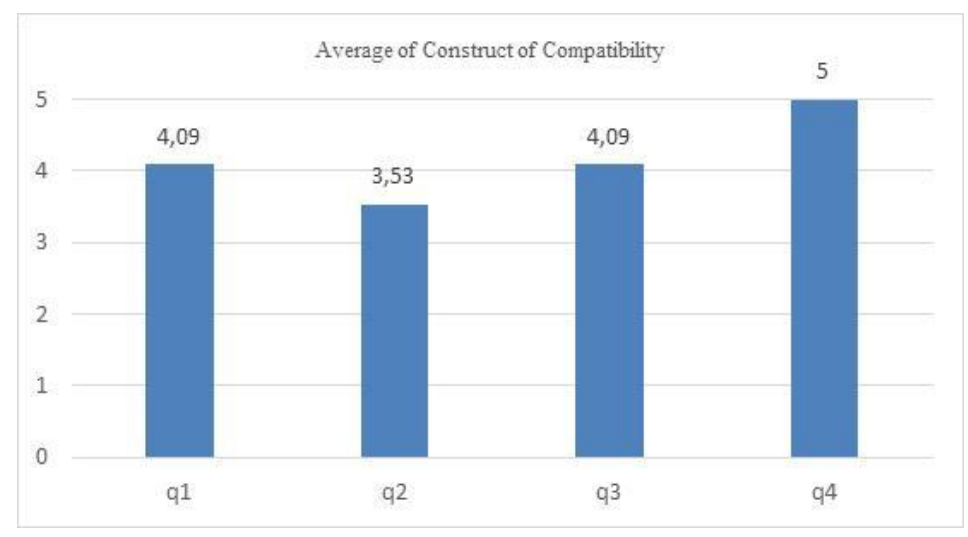

Figure 4. Average for construct of compatibility

\subsection{Construct of Using Intention}

The fifth construct is the construct of using intention, [18-19] which refers to the intention of individuals of using mobile in the future [18] [20], and refers to Table 5. As we can see here, the students are willing to use and will continue to use this application to learn basic numbers. We can say that the students are willing to continue using interactive technology. They have found that future intention and the characteristics of students have a significant positive effect on students continued use of ARBEST. The interactive technology also suggests that a student's level of innovativeness affects his or her acceptance of innovative interactive technology [21]. From the bar chart, we can see that all the students had strongly agreed that they are willing to use ARBEST to learn numbers. All the students had strongly agreed that they will continue using ARBEST to learn numbers in the future. All the students had strongly agreed that they will recommend to their friends to learn numbers through ARBEST, as shown in Figure 5.

Table 5. Questions for Construct of using Intention

\begin{tabular}{ll}
\hline 5. CONSTRUCT OF USING INTENTION = It refers to the intention of individuals of using mobile in the future. \\
\hline $\mathrm{q} 1$ & I am willing to use ARBEST to learn numbers \\
$\mathrm{q} 2$ & I will continue using ARBEST to learn numbers in the future \\
$\mathrm{q} 3$ & Overall, I will use ARBEST to learn numbers \\
$\mathrm{q} 4$ & I will recommend others learning numbers through ARBEST \\
\hline
\end{tabular}




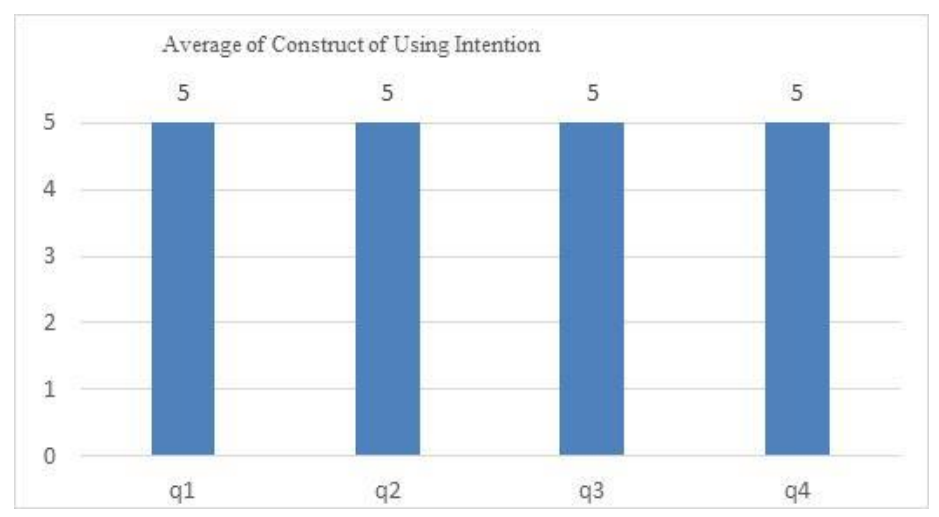

Figure 5. Average for construct of using intention

\section{CONCLUSION}

By looking at the graph above, we can say that the students enjoy learning using ARBEST and they are willing to use in it the future without facing any problems. ARBEST is a novel approach to assist the LINUS students and teachers by using the augmented reality mobile application. Each questionnaire tested the usability of the application. This application helps the LINUS students in learning basic numbers with much joy. For future development in order to improve the application and the quiz usability, it is suggested that each navigational button can be analyzed for each time they click. This is important to ensure the number of times they need to click or pick the correct answer.

\section{ACKNOWLEDGEMENT}

We would like to acknowledge Bahagian Perancangan Dan Penyelidikan Dasar Pendidikan, Kementerian Pendidikan Malaysia (KPM), Jabatan Pendidikan Negeri Terengganu (JPNT), SK Kubu, SK Undang, SK Tok Dir, and the Ministry of Education who supported this study. This research is supported by Universiti Sultan Zainal Abidin (UniSZA).

\section{REFERENCES}

[1] M. W. Ok, M. K. Kim, E. Y. Kang, and B. R. Bryant, "How to Find Good Apps: An Evaluation Rubric for Instructional Apps for Teaching Students With Learning Disabilities,” Interv. Sch. Clin., vol. 51, no. 4, pp. 244 $252,2016$.

[2] M. Education Malaysia, "Malaysia Education Blueprint 2013-2025 (Preschool to Post-Secondary Education)," Minist. Educ. Malaysia, p. 292, 2013.

[3] W. Fatimah, W. Ahmad, A. S. Hashim, and A. Nadia, "Development of Mobile Application for Autistic Children Using Augmentative and Alternative Communication Technique," no. 013, pp. 262-267, 2017.

[4] Nazariyah Sani and Abdul Rahman Idris, "Implementation Of Linus Programme Based On The Model Of Van Meter And Van Horn,” Malaysian Online J. Educ. Sci., vol. 1, no. 2, pp. 25-36, 2012.

[5] A. J. Othman, "Cabaran Guru Program Linus Dalam Pengajaran dan Pembelajaran Bahasa," pp. 37-51, 2011.

[6] M. N. Hj. Mohd Razak, S. Shaharuddin, and K. Normah, "Cabaran Guru Pemulihan Linus (Literasi) Di Sekolah Sekolah Murid Orang Asli Negeri Perak," J. Penyelid. Dedik., vol. 8, no. Institut Pendidikan Guru Kampus Ipoh, pp. 1-18, 2014.

[7] S. Z. Ahmad and A. A. Mutalib, "Preliminary study: An investigation on learning assistance requirement among low achievers in primary schools," Int. J. Comput. Appl., vol. 114, no. 2, pp. 975-8887, Mar. 2015.

[8] A. A. Norabeerah Saforrudin, Halimah Badioze Zaman, "Pengajaran Masa Depan Menggunakan Teknologi Augmented Reality Dalam Pendidikan Bahasa Melayu: Tahap Kesedaran Guru," Malay Lang. Educ. J. - MyLEJ, vol. 2, pp. 1-10, Nov. 2012.

[9] K. Awang, S. Nor, W. Shamsuddin, and I. Ismail, "A Conceptual Framework for Designing Mobile Augmented Reality in Learning Basic Numbers," vol. 35, no. 7, pp. 1048-1053, 2017.

[10] S. Faridah and S. Mahadi, "A Review of Learning Courseware for Children with Learning Disabilities in Malaysia," J. Inf. Syst. Res. Innov., vol. 10, no. December, pp. 1-8, 2016.

[11] Y. S. Ryu and T. L. Smith-Jackson, "Reliability and Validity of the Mobile Phone Usability Questionnaire (MPUQ)," J. Usability Stud., vol. 2, no. 1, pp. 39-53, 2006.

[12] J. Brooke, "SUS - A quick and dirty usability scale," Usability Eval. Ind., vol. 189, no. 194, pp. 4-7, 1996.

[13] H. Tüzün, M. Yilmaz-Soylu, T. Karakuş, Y. Inal, and G. Kizilkaya, "The effects of computer games on primary school students' achievement and motivation in geography learning," Comput. Educ., vol. 52, no. 1, pp. 68-77, 2009. 
[14] C. V. Check, "Mobile Application Usability : Conceptualization And Instrument Development," vol. 39, no. 2, pp. $1-12,2015$.

[15] O. E. D. Online, “Oxford English Dictionary Online," Oxford English Dict., vol. 2010, no. 07/07, p. http://dictionary.oed.com/, 2010.

[16] D. R. A. Rambli, W. Matcha, and S. Sulaiman, "Fun Learning with AR Alphabet Book for Preschool Children," Procedia Comput. Sci., vol. 25, pp. 211-219, 2013.

[17] G.-J. Hwang, P.-H. Wu, and C.-C. Chen, "An online game approach for improving students' learning performance in web-based problem-solving activities," Comput. Educ., vol. 59, no. 4, pp. 1246-1256, Dec. 2012.

[18] H. Chung, S. Chen, and M. Kuo, "A study of EFL college students ' acceptance of mobile learning," vol. 176, pp. 333-339, 2015.

[19] H. van der Heijden, "v iiicir c i Iv research n ? te User User Acceptance of Hedonic Information Systems," vol. 28, no. 4, pp. 695-704, 2016

[20] S. Taylor and P. Todd, “Assessing IT Usage: The Role of Prior Experience," MIS Q., vol. 19, no. 4, p. 561, 1995.

[21] T. L. Huang and S. Liao, "A model of acceptance of augmented-reality interactive technology: the moderating role of cognitive innovativeness," Electron. Commer. Res., vol. 15, no. 2, pp. 269-295, 2015. 